
ISSN : 2615-1995, E-ISSN : 2615-0654

J. Madani., Vol. 2, No. 1, Maret 2019 (115 - 128)

(C)2018 Lembaga Kajian Demokrasi

MADANI

dan Pemberdayaan Masyarakat (LKD-PM)

\title{
ANALISIS HUBUNGAN KUALITAS PELAYANAN DAN PERSEPSI HARGA DENGAN KEPUASAN KONSUMEN (STUDI KASUS DI RUANG KENANGA RAWAT INAP RSUD KABUPATEN TANGERANG)
}

\author{
Didi Sujadi \\ Fakultas Ekonomi, Universitas Pamulang \\ didisujadi@yahoo.co.id
}

\begin{abstract}
Abstrak
Judul penelitian ini adalah Analisis Hubungan Kualitas Pelayanan Dan Persepsi Harga Dengan Kepuasan Konsumen. Penelitian ini dilakukan di rumah sakit umum daerah kabupaten tangerang dengan objek peneliti ini adalah pasien di rumah sakit umum daerah Kabupaten Tangerang di ruang kenanga instalasi rawat inap. Tujuan penelitian ini adalah untuk menganalisis hubungan kualitas pelayanan dan persepsi harga dengan kepuasan konsumen. Penelitian ini merupakan penelitian kuantitatif dengan menggunakan Metode Survey non kausal, metode ini menggunakan analisis regresi berganda yang menguraikan hubungan antar variabel yang diteliti yaitu hubungan antar variabel independen variabel dependen. Untuk variabel independen adalah kualitas pelayanan $\left(X_{1}\right)$ dan persepsi harga $\left(X_{2}\right)$, sedangkan variabel dependen $(Y)$ adalah kepuasan konsumen. Guna menjawab rumusan masalah diatas, peneliti menyebarkan angket kuesioner di rumah sakit umum daerah Kabupaten Tangerang dengan jumlah populasi 348, sampel yang diambil sebanyak 87 orang pasien. Hasil penelitian diatas menunjukkan bahwa (1). Terdapat hubungan positif yang signifikan antara kualitas pelayanan dengan kepuasan konsumen dilihat dari uji t pada variable kualitas pelayanan 6.626 dan signifikan $0.000 T_{\text {tabel }}$ yang nilainya 1.658 dengan tingkat signifikan kurang dari 0,05. (2) dari hasil uji t pada persepsi harga adalah 0,927 dan signifikan sebesar 0,000 $T_{\text {hitung }}<t_{\text {tabel }}$ yang nilainya 1.658 dengan tingkat signifikan 0,000 lebih kecil dari 0,05 maka dapat diketahui bahwa persepsi harga terdapat hubungan yang signifikan terhadap kepuasan konsumen.
\end{abstract}

Kata Kunci : Kualitas Pelayanan, Persepsi Harga, Kepuasan Konsumen.

\begin{abstract}
The title of this research is the analysis Relations Service Quality And Customer Satisfaction With Price Perception. This research was conducted in a public hospital district tangerang with the object of this research is patient in a public hospital district ruamh tangerang in space ylang inpatient. The purpose of this study was to analyze the relationship between service quality and price perception with consumer satisfaction. This research is a quantitative study using non-causal Survey method, this method using multiple regression analysis that illustrate the relationship between the variables studied the relationship between the independent variable dependent variable. For the independent variable is the quality of service $\left(X_{1}\right)$ and the perception of price $\left(X_{2}\right)$, while the dependent variable $(Y)$ is the consumer satisfaction. To answer the formulation of the above problems, researchers deploy questionnaires in public hospitals Tangerang district with a population of 348 samples taken as many as 87 patients. The above results show that (1). There is a significant positive relationship between service quality and customer satisfaction views of the $t$ test on the variable quality of service and significant 6,626 0,000 1,658 T whose value table with a significant level of less than 0.05. (2) of the test results on the perception of price is 0.927 and significant of $0,000 \mathrm{~T}<t$ table whose value 1,658 with a significant level of 0.000 less than 0.05 it can be seen that the price perception of a significant correlation to customer satisfaction.
\end{abstract}

Keywords : Quality of Service, Price Perception, Customer Satisfaction. 


\section{PENDAHULUAN}

\section{Latar Belakang}

Perkembangan jaman yang begitu pesat diiringi dengan kemajuan teknologi dan informasi berdampak pada persaingan bisnis yang semakin kompetitif. Perusahaan-perusahaan melakukan berbagai inovasi dan kreatifitas dalam membangun strategi untuk mempertahankan dan mampu menjual produknya dipasaran. Keadaan ini, membuat perusahaan berupaya menciptakan nilai dan kepuasan terhadap produk yang dihasilkan oleh perusahaan.

Kesehatan yang merupakan salah satu elemen terpenting pada diri manusia dan merupakan salah satu tujuan nasional dalam mensejahterakan bangsa sebagai bentuk regenerasi yang sehat dan kuat. Begitu pentingnya kesehatan bagi masyarakat, dikarenakan sebagai investasi sumber daya jangka panjang untuk regenerasi bangsa ini. Sebagaimana tertuang dalam undang-undang Republik Indonesia no.36 tahun 2014 tentang tenaga kesehatan. Bahwa tenaga kesehatan memiliki peranan penting untuk meningkatkan kualitas pelayanan kesehatan yang maksimal kepada masyarakat sebagai investasi bagi pembangunan sumber daya manusia yang produktif secara sosial dan ekonomi serta sebagai salah satu unsur kesejahteraan umum sebagaimana dimaksud dalam pembukaan undangundang dasar negara republik Indonesia tahun 1945.

Rumah sakit dalam menumbuhkembangkan tidak terlepas dari kualitas pelayanan yang baik dan profesionalitas. Sehingga memberikan persepsi positif di benak pelanggannya. Dengan harga yang terjangkau dapat memenuhi kebutuhan pelanggan tanpa mengendahkan sebuah kualitas pelayanan yang baik.

Perusahaan bidang jasa rumah sakit tidak terlepas dari kegiatan pemasaran dalam hal kualitas pelayanan untuk memenuhi kepuasan pasiennya. Manajemen rumah sakit yang dikelola dengan baik akan memberikan dampak positif bagi pelanggannya dan yang terpenting adalah menetapkan arah tujuan perusahaan, memberikan kepemimpinan untuk mencapai tujuan tersebut serta membuat keputusan mengenai bagaimana menggunakan sumber daya organisasi untuk mencapai tujuan-tujuan yang telah ditetapkan.

Berdasarkan fenomena yang dikemukakan sebelumnya dan mengacu pada beberapa penelitian, masalah yang dapat diangkat dalam penelitian ini adalah menguji hubungan antara kualitas pelayanan dan persepsi harga dengan kepuasan konsumen di rumah sakit umum daerah Kabupaten Yangerang.

\section{Tujuan Penelitian}

Tujuan penelitian ini adalah dapat berguna dan bermanfaat bagi penulis dan bagi pihak lain yang bersangkutan.

1. Untuk mengetahui hubungan kualitas pelayanan dengan kepuasan konsumen di rumah sakit umum daerah Kabupaten Tangerang.

2. Untuk mengetahui proses persepsi harga dengan kepuasan konsumen di rumah sakit umum daerah Kabupaten Tangerang.

3. Untuk mengetahui hubungan kualitas pelayanan dan persepsi harga secara simultan dengan kepuasan konsumen di rumah sakit umum daerah Kabupaten Tangerang.

\section{Tinjauan Pustaka \\ Pengertian Manajemen \\ dan Manajemen Pemasaran}

Manajemen sebagai salah satu bidang ilmu pengetahuan yang secara sistematis untuk memahami mengapa dan bagaimana manusia bekerja bersama untuk mencapai tujuan dan membuat sistem kerjasama ini bermanfaat bagi manusia. Manajemen sebagai seniuntuk mencapai hasil yang maksimal dengan usaha yang minimal, demikian pula mencapai kesejateraan dan kebahagiaan maksimal bagi pimpinan maupun pekerja serta memberikan pelayanan yang sebaik mungkin kepada masyarakat. Tentunya peran manajemen sangat dibutuhkan dalam kehidupan sehari-hari yang diperuntukkan untuk mengatur segala pekerjaan, sehingga dapat menyelesaikan tugas dengan baik secara sistematis.manajemen sebagai profesi merupakan suatu bidang pekerja yang dilakukan oleh orang-orang yang memiliki keahlian dan keterampilan dalam suatu organisasi atau perusahaan.

Menurut Mary Parker Follet (Daft dan Marcic, 2007) menegaskan bahwa pada dasarnya manajemen adalah, "the art of getting things done through people" (seni menyelesaikan suatu pekerjaan melalui orang lain). Sedangkan Koontz mempopulerkan konsep fungsi-fungsi manajemen dengan mengelompokkan tugas-tugas yang dilakukan oleh manajemen ke dalam lima fungsi manajemen, yaitu : perencanaan (planning), pengorganisasian (organizing), pengisian staf (staffing), memimpin (leading), dan pengendalian (controlling).

Hersey dan Blanchard (1980: 3 alih bahasa dalam Siswanto 2011 : 2) memberikan batasan manajemen "sebagai suatu usaha yang dilakukan dengan dan bersama individu atau kelompok untuk mencapai tujuan organisasi".

Di dalam manajemen dalam mencapai suatu tujuan organisasi, sumber daya manusia merupakan peranan yang paling penting agar ter- 
ciptanya tujuan organisasi atau intansi. Berikut adalah fungsi operasional manajemen sumber daya manusia menurut M. Yani (2012 : 4-5). Fungsi operasional dalam Manajemen Sumber Daya Manusia merupakan dasar pelaksanaan MSDM yang efesien dan efektif dalam pencapaian tujuan organisasi atau perusahaan. Manajemen Sumber Daya Manusia secara fungsional memiliki beberapa fungsi yang saling terkait satu sama lain dan operasional yang dijalankan oleh Manajemen Sumber Daya Manusia sesuai dengan fungsi yang dimilikinya. Dan Manajemen keuangan berkepentingan dengan bagaimana cara menciptakan dan menjaga nilai ekonomis atau kekayaan. "Manajemen keuangan menyangkut kegiatan perencanaan, analisis dan pengendalian kegiatan keuangan" (Husnan dan Pudjiastutui, $2012: 4)$.

Sedangkan manajemen pemasaran berasal dari dua kata yaitu manajemen dan pemasaran. Menurut Kotler dan Armstrong pemasaran adalah analisis, perencanaan, implementasi, dan pengendalian dari program-program yang dirancang untuk menciptakan, membangun, dan memelihara, pertukaran yang menguntungkan dengan pembeli sasaran untuk mencapai tujuan perusahaan.

Pemasaran jasa adalah perencanaan yang bergerak dari fokus pada transaksi menjadi hubungan jangka panjang dengan pelanggan. Menurut Kotler dan Armstrong (2012), menyatakan bahwa jasa adalah segala aktivitas dan berbagai kegiatan atau manfaat yang ditawarkan untuk dijual boleh suatu pihak kepada pihak lain yang secara esensial jasa ini tidak berwujud dan tidak menghasilkan perpindahan kepemilikan atas apapun.

\section{Pengertian Kualitas}

Kualitas merupakan suatu kondisi dinamis yang berpengaruh dengan produk, jasa, manusia, proses dan lingkungan yang memenuhi atau melebihi harapan (Tjiptono, 2012 : 51). Dalam perpektif TQM (Total Quality Management) kualitas dipandang secara luas, yaitu tidak hanya aspek hasil yang ditekankan, tetapi juga meliputi proses, lingkungan dan manusia. Sedangkan menurut Garvin yang dikutip Tjiptono (2012 : 143) menyatakan bahwa terdapat lima perspektif mengenai kualitas, salah satunya yaitu bahwa kualitas dilihat tergantung pada orang yang menilainya, sehingga produk yang paling memuaskan preferensi seseorang merupakan produk yang berkualitas paling tinggi. Kualitas pelayanan dapat diketahui dengan cara membandingkan persepsi para konsumen atas pelayanan yang nyata-nyata mereka terima atau peroleh dengan pelayanan yang sesungguhnya mereka harapkan atau inginkan terhadap atributatribut pelayanan suatu perusahaan. Jika jasa yang diterima atau dirasakan (perceivedservice) sesuai dengan harapan, maka kualitas pelayanan dipersepsikan baik dan memuaskan, jika jasa yang diterima melampaui harapan konsumen, maka kualitas pelayanan dipersepsikan sangat baik dan berkualitas. Sebaliknya jika jasa yang diterima lebih rendah daripada yang diharapkan maka kualitas pelayanan dipersepsikan buruk.

Menurut Jusuf Suit dan Almasdi (2012 : 88) untuk melayani pelanggan secara prima kita diwajibkan untuk memberikan layanan yang pasti handal, cepat serta lengkap dengan tambahan empati dan penampilan menarik. Pengertian kualitas jasa atau pelayanan berpusat pada upaya pemenuhan kebutuhan dan keinginan pelanggan serta ketetapan penyampaiannya untuk mengimbangi harapan pelanggan.Dan menurut Lewis \& Booms (dalam Tjiptono, 2012 : 157) mendefinisikan kualitas pelayanan secara sederhana, yaitu ukuran seberapa bagus tingkat layanan yang diberikan mampu sesuai dengan ekspektasi pelanggan. Artinya kualitas pelayanan ditentukan oleh kemampuan perusahaan atau lembaga tertentu untuk memenuhi kebutuhan yang sesuai dengan apa yang diharapkan atau diinginkan berdasarkan kebutuhan pelanggan/ pengunjung dan persepsi masyarakat terhadap pelayanan tersebut. Nilai kualitas pelayan tergantung pada kemampuan perusahaan dan stafnya dalam memenuhi harapan pelanggan secara konsisten.

Sedangkan menurut Phillip Kotler dan Keller Kevin Lane (2007 : 180) dalam Rahmatriana (2013) kualitas adalah keseluruhan fitur dan sifat produk atau pelayanan yang berpengaruh pada kemampuannya untuk memuaskan kebutuhan yang dinyatakan atau yang tersirat.

Kemudian ISO 9000 yang merupakan kumpulan standar untuk sistem manajemen mutu (SMM). menurut buku Rambat Lupiyoadi (2014 : 212) kualitas adalah perpaduan antara sifat dan karakteristik yang menentukan sejauh mana keluaran dapat memenuhi persyaratan kebutuhan pelanggan. Pelanggan yang menentukan dan menilai sampai seberapa jauh sifat dan karakteristik tersebut memenuhi kebutuhannya.

Berdasarkan pengertian kualitas tersebut, maka penulis menyimpulkan bahwa pemenuhan standar atau persyaratan tertentu, kualitas juga mempunyai pengertian sebagai upaya untuk melakukan perbaikan dan penyempurnaan secara terus-menerus dalam pemenuhan kebutuhan pelanggan sehingga dapat memuaskan konsumen.

\section{Pengertian Pelayanan}

Pelayanan dalam hal ini sangat erat dengan 
kepuasan terhadap pelanggan, pelayanan dengan mutu yang baik dapat memberikan dampak positif bagi konsumen dalam hal kepuasan dimana pelanggan merasa diperhatikan oleh perusahaan.

Menurut Fandy Tjiptono (2012: 4) pelayanan (service) bisa dipandang sebagai sebuah sistem yang terdiri atas dua komponen utama, yakni service operations yang kerap kali tidak tampak atau tidak diketahui keberadaannya oleh pelanggan (back office atau backstage) dan service delivery yang biasanya tampak (visible) atau diketahui pelanggan (sering disebut pula front office atau frontstage), dan menurut Fandy Tjiptono (2012: 28) jasa atau pelayanan memiliki empat karakteristik utama yaitu :

1) Tidak berwujud (Intangibility)

Jasa atau layanan berbeda secara signifikan dengan barang fisik.Bila barang merupakan suatu objek, alat, material atau benda yang bisa dilihat, disentuh dan dirasa dengan panca indera; maka jasa/layanan justru merupakan perbuatan, tindakan, pengalaman, proses, kinerja (performance), atau usaha yang sifatnya abstrak. Bila barang dapat dimiliki, maka jasa/ layanan cenderung hanya dapat dikonsumsi tetapi tidak dapat dimiliki (non-ownership). Jasa bersifat intangible, artinya jasa tidak dapat dilihat, dirasa, dicium, didengar atau diraba sebelum dibeli dan dikonsumsi. Seorang konsumen jasa tidak dapat menilai hasil dari sebuah jasa sebelum ia mengalami atau mengkonsumsinya sendiri.

2) Bervariasi (Heterogeneity)

Layanan bersifat variabel atau heterogen karena merupakan non-standardized output, artinya bentuk, kualitas dan jenisnya sangat beraneka ragam, tergantung pada siapa, kapan, dan dimana layanan tersebut dihasilkan. Terdapat tiga faktor yang menyebabkan variabilitas kualitas jasa, yaitu : (1) kerjasama atau partisipasi pelanggan selama penyampaian layanan; (2) moral/motivasi karyawan dalam melayani pelanggan; serta (3) beban kerja perusahaan.

3) Tidak terpisahkan (inseparability)

Barang biasanya diproduksi terlebih dahulu, kemudian dijual, baru dikonsumsi. Sedangkan jasa umumnya dijual terlebih dahulu, baru kemudian diproduksi dan dikonsumsi pada waktu dan tempat yang sama. Interaksi antara penyedia jasa dan pelanggan merupakan ciri khusus dalam pemasaran jasa/layanan bersangkutan. Keduanya mempengaruhi hasil (outcome) dari jasa/layanan bersangkutan. Dalam hubungan antara penyedia jasa dan pelanggan ini, efektifitas staf layanan merupakan unsur kritis. Implikasinya, sukses tidaknya jasa/layanan bersangkutan ditunjang oleh kemampuan organisasi dalam melakukan proses rekruitmen dan seleksi, penilaian kinerja, sistem kompensasi, pelatihan, dan pengembangan secara efektif.

4) Tidak tahan lama (perishability)

Perishability berarti bahwa jasa/layanan adalah komoditas yang tidak tahan lama, tidak dapat disimpan untuk pemakaian ulang di waktu yang akan datang, dijual kembali, atau dikembalikan. Permintaan jasa juga bersifat fluktuasi dan berubah, dampaknya perusahaan jasa seringkali mengalami masalah sulit. Oleh karena itu perusahaan jasa merancang strategi agar lebih baik dalam menjalankan usahanya dengan menyesuaikan permintaan dan penawaran.

Menurut Kotler dan Keller (2013 : 378) menyatakan bahwa : "A service is any act or performance one party can offter to another that is essentially intangible and does not result in the ownership of anything". Dari definisi ini dapat diartikan bahwa pelayanan adalah setiap tindakan atau kegiatan yang dapat ditawarkan oleh suatu pihak kepada pihak lain yang pada dasarnya tidak berwujud dan tidak mengakibatkan kepemilikan apapun.

Sedangkan enurut Gronroos dalam Tjiptono (2012) menyatakan bahwa pelayanan merupakan proses yang terdiri atas serangkaian aktifitas intangible yang bisa (namun tidak harus selalu) terjadi pada interaksi antara pelanggan dan karyawan, jasa dan sumber daya, fisik atau barang, dan sistem penyedia jasa, yang disediakan sebagai solusi atas masalah pelanggan.

Kemudian menurut Daryanto dan Setyobudi (2014 : 135) dalam Rahmatriana (2013) pelayanan adalah setiap kegiatan yang menguntungkan dalam suatu kumpulan atau kesatuan, dan menawarkan kepuasan meskipun hasilnya tidak terikat pada suatu produk secara fisik.

Berdasarkan kompetisi dan kebutuhan personal, konsumen akan memilih penyedia layanan (service provider) berdasarkan Sembilan kriteria menurut Fitzsimmons (2011: 45) sebagai berikut:

1. Availability

Seberapa mudah ketersediaan layanan tersebut dapat di akses?

2. Convenience

Apakah lokasi yang menjadi tempat penyedia jasa memberikan kenyamanan bagi pelanggan?

3. Dependability

Apakah layanan yang ditawarkan dapat diandalkan?

4. Personaliaztion

Apakah penyedia layanan tersebut memberikan pelayanan secara personal? 
5. Price

Apakah harga yang ditentukan sesuai dengan kualitas pelayanan yang diberikan?

6. Quality

Kualitas sangat menentukan nilai dalam proses pennyampaian layanan dan hasil dari layanan tersebut. Kualitas pelayanan merupakan fungsi dari hubungan antara harapan dan persepsi pelanggan terhadap pelayanan tersebut.

7. Reputation

Reputasi yang baik atau nama baik penyedia layanan dalam masyarakat akan menentukan pilihan konsumen dalam memilih penyedia layanan jasa. Reputasi yang buruk tidak dapat dikembalikan seperti halnya produk yang rusak dapat diganti dengan model atau barang yang baru. Reputasi yang baik sangat penting untuk dijaga oleh perusahaan penyedia layanan jasa.

8. Safety

Keamanan dan keselamatan merupakan hal yang menjadi pertimbangan utama konsumen.

9. Speed

Berapa lama waktu yang diperlukan untuk menunggu layanan tersebut? kecepatan dalam pemberian layanan menjadi hal penting bagi pertimbangan konsumen dalam memilih penyedia layanan.

Berdasarkan pengertian pelayanan tersebut, maka dapat disimpulkan bahwa pelayanan merupakan suatu kegiatan interaksi antara konsumen dan karyawan yang disediakan oleh perusahaan pemberi layanan jasa.

\section{Dimensi Pokok Kualitas Layanan}

Dimensi pokok kualitas pelayanan menurut Parasuraman, Zeithaml, dan Berry (1985) yang dikutip oleh Fandy Tjiptono (2012: 174) terdapat lima dimensi pokok untuk mengukur kualitas layanan yaitu :

1) Reabilitas (reability), berkaitan dengan kemampuan perusahaan memberikan layanan yang disajikan secara akurat dan memuaskan.

2) Daya tanggap (Responsiveness), berkenaan dengan kesediaan dan kemampuan penyedia layanan untuk membantu para pelanggan dan merespon permintaan mereka dengan segera.

3) Jaminan (Assurance), berkenaan dengan pengetahuan dan kesopanan karyawan serta kemampuan mereka dalam menumbuhkan rasa percaya (trust) dan keyakinan pelanggan (confidence).

4) Empati (Empaty), berarti bahwa perusahaan memahami masalah para pelanggannya dan bertindak demi kepentingan pelanggan, ser- ta memberikan perhatian personal dan pemahaman atas kebutuhan individual para pelanggan tersebut.

5) Bukti fisik (Tangibles), berkenaan dengan penampilan fisik, fasilitas layanan, peralatan/ perlengkapan, sumber daya manusia, dan materi komunikasi perusahaan.

Berdasarkan penjelasan di atas, maka kualitas pelayanan dapat disimpulkan sebagai bentuk interaksi antara konsumen dan karyawan (perusahaan penyedia jasa) dalam upaya penyempurnaan secara continue dalam memenuhi kebutuhan pelanggan dengan tujuan memuaskan kebutuhan konsumen.

\section{Pengertian Persepsi}

Pada dasarnya konsumen merupakan individu dengan karakteristik yang berbeda-beda dan penilaian yang dirasakan pun setiap konsumen terhadap suatu produk atau jasa yang mereka persepsikan tidak akan sama, karena persepsi konsumen tentang harga dapat mempengaruhi dalam pengambilan keputusan dalam membeli suatu produk atau jasa.

Definisi persepsi menurut beberapa tokoh diantaranya ialah:

1) Leavitt (dalam Desmita, 2011 : 117) mendefinisikan "Perception dalam pengertian sempit adalah penglihatan, yaitu bagaimana seseorang melihat sesuatu; sedangkan dalam arti luas, perception adalah pandangan, yaitu bagaimana seseorang memandang atau mengartikan sesuatu".

2) Jalaluddin Rakhmat (2011:48) menyatakan persepsi adalah suatu proses member makna pada sensasi sehingga manusia mendapatkan pengetahuan baru.

3) Suranto (2011:63) persepsi adalah suatu proses menafsirkan stimuli-stimuli yang diperoleh indera manusia. Proses indera menangkap stimuli dinamakan sensasi. Jadi, sensasi adalah proses menangkap stimuli. Agar stimuli tersebut memiliki makna, maka komunikasi melakukan persepsi yang bergantung pada pikiran dan perasaannya.

Dari definisi tersebut dapat disimpulkan bahwa persepsi adalah suatu proses pemberian arti terhadap objek yang diterima dengan melalui tahap penyeleksian, pengorganisasian yang ditangkap oleh panca indera dan menginterpretasikanya menjadi suatu yang bermakna.

\section{Pengertian Harga}

Penetapan harga memerlukan suatu pendekatan tujuan dan mengembangkan suatu struktur penetapan harga yang tepat. Pengertian harga menurut Basu Swastha (2010 : 147) adalah sejumlah uang yang dibutuhkan untuk mendapat sejumlah kombinasi dari barang beserta pela- 
yanannya. Harga seringkali digunakan sebagai indikator nilai bagaimana harga tersebut dihubungkan dengan manfaat yang dirasakan atas suatu barang atau jasa.

Menurut Peter \& Olson (2008 : 405) berpendapat bahwa : "Price can also create brand images as well as provide a functional competitive advantage. In terms of brand images, high prices can connate high quality for some products; and it is often stated that consumers perceive a relationship between price and quality. Artinya adalah harga dapat menggambarkan suatu merek dan memberikan keunggulan kompetitif fungsional. Dalam menggambarkan merek, harga tinggi dapat diketahui berkualitas tinggi untuk beberapa produk yang sering dinyatakan bahwa konsumen merasakan hubungan antara harga dan kualitas.

Persepsi harga berkaitan dengan bagaimana informasi harga dipahami seluruhnya oleh konsumen dan memberikan makna yang dalam bagi mereka.Pada saat pemrosesan informasi harga secara kognitif terjadi, konsumen dapat membuat perbandingan antara harga yang ditetapkan dengan sebuah harga atau rentang harga yang telah terbentuk dalam benak mereka untuk produk tersebut.

Kotler dan Keller (2012) mendefinisikan harga adalah jumlah uang (kemungkinan ditimbang beberapa barang) yang dibutuhkan untuk memperoleh beberapa kombinasi sebuah produk dan pelayanan yang menyertainya.

Penilaian harga dapat dilihat dari kesesuaian antara suatu pengorbanan dari konsumen terhadap nilai yang diterimanya setelah melakukan pembelian, dan dari situlah konsumen akan mempersepsikan dari produk atau jasa tersebut. Persepsi yang positif merupakan hasil dari rasa puas akan suatu pembelian yang dilakukannya, sedangkan persepsi yang negatif merupakan suatu bentuk dari ketidakpuasan konsumen atas produk atau jasa yang dibelinya, indicator dari harga antara lain :

- Kesesuaian harga produk dengan kualitas produk.

- Perbandingan harga dengan harga produk lain dan sejenis.

- Kesesuaian harga produk dengan manfaat yang di dapat.

Dalam memasarkan suatu jasa agar berhasil, setiap perusahaan harus menetapkan harga secara tepat kepada konsumen yang mencari sasaran utamanya. Harga merupakan satu-satunya unsur bauran pemasaran yang memberikan pemasukan atau pendapatan bagi perusahaan. Harga mengkoordinasikan keputusan-keputusan para produsen dan konsumen dalam sebuah pasar. Harga-harga yang lebih tinggi cenderung yang lebih rendah mendorong konsumsi dan meng- hambat produksi. Harga adalah roda penyeimbang dari mekanisme harga.

Menurut Malik dan Yaqoob (2012 :487) persepsi harga adalah "The process by which consumers interpret price and attribute value to a good or service process". Yang berarti sebuah proses dimana pelanggan menafsirkan nilai harga dan atribut ke barang atau pelayanan yang di inginkan.

Sedangkan menurut Xia et al dalam Lee dan Lawson-Body (2011 : 532) bahwa persepsi harga merupakan penilaian pelanggan dan bentuk emosional yang terasosiasi mengenai apakah harga yang ditawarkan oleh penjual dan harga yang dibandingkan dengan pihak lain masuk diakal, dapat diterima atau dapat dijustifikasi.

Kemudian menurut Adrian Payne yang dikutip oleh Danang Sunyoto (2013 : 172) tujuan penetapan harga sebagai berikut :

1) Bertahan

Bertahan merupakan usaha untuk tidak melakukan tindakan-tindakan yang meningkatkan laba ketika perusahaan sedang mengalami kondisi pasar yang tidak menguntungkan.

2) Memaksimalkan laba

Penetapan harga bertujuan untuk memaksimalkan laba dalam periode tertentu.

3) Memaksimalkan penjualan

Penentuan harga bertujuan untuk membangun pangsa pasar dengan melakukan penjualan pada harga awal yang merugikan.

4) Prestise

Tujuan penentuan harga disini adalah untuk memposisikan jasa perusahaan tersebut sebagai produk yang ekslusif.

5) Pengembangan atas investasi

Tujuan penentuan harga didasarkan atas pencapaian pengembalian atas investasi (return on investment) yang diinginkan.

Adapun setiap perusahaan memiliki kebijakan berbeda dalam menetapkan harga yang disesuaikan dengan tujuan yang hendak dicapai oleh suatu perusahaan. Hal ini tidak lepas dari keputusan yang dibuat sebelumnya oleh perusahaan mengenai penempatan pasar. Pertama kali perusahaan harus menentukan terlebih dahulu apa yang ingin dicapai dari suatu produk tertentu. Bila perusahaan telah menjatuhkan pilihannya pada suatu pasar sasaran dengan penempatan pasar tertentu, maka strategi bauran pemasaran, termasuk harga akan lebih cepat ditentukan (Kotler, 2012).

Berdasarkan pengertian persepsi harga diatas, maka dapat disimpulkan bahwa biaya yang dikeluarkan oleh konsumen memiliki harapan suatu produk/jasa sesuai dengan keinginan dan harga yang ditetapkan terjangkau, serta memberikan manfaat bagi konsumen. 


\section{Pengertian kepuasan pelanggan}

Kepuasan berasal dari bahasa latin "Satis", yang cukup baik dan memadai, sedangkan "Facio" artinya melakukan atau membuat. Jadi kepuasan bisa diartikan sebagai "upaya pemenuhan sesuatu. "Menurut Kotler yang dikutip kembali oleh Fandy Tjiptono (2012 : 312) kepuasan konsumen adalah tingkat perasaan seseorang setelah membandingkan kinerja (atau hasil) yang ia persepsikan dibandingkan dengan harapannya.

Sedangkan kepuasan dapat didefinisikan sebagai perilaku pelanggan dalam menilai sebuah produk berdasarkan tindakan sebelumnya atau pemakaian produk (Lovelock \& Wirtz, 2007). Dan kepuasan pelanggan menurut Zeithaml, Bitner dan Dwayne (2009:104) adalah, "Customer's evaluation of a product or service in terms of whether that product or service has me the customer's needs and expectations".Di mana menurut kepuasan pelanggan adalah penilaian pelanggan atas produk ataupun jasa dalam hal menilai apakah produk atau jasa tersebut telah memenuhi kebutuhan dan ekspektasi pelanggan.

Pelanggan adalah orang yang menerima hasil pekerjaan seseorang atau organisasi, maka yang dapat menentukan kualitasnya seperti apa yang mereka dan mereka dapat menyampaikannya apa dan bagaimana kebutuhan mereka. Setiap orang dalam perusahaan harus bekerja dengan pelanggan internal dan eksternal untuk menentukan kebutuhan mereka dan bekerja sama dengan pemasok internal dan ekseternal. Ada beberapa unsur penting dalam kualitas yang ditentukan pelanggan yaitu: pelanggan harus merupakan prioritas utama perusahaan, dan dapat diandalkan sebagai pelanggan yang telah melakukan pembelian berkali-kali (pembelian ulang) pada perusahaan yang sama. Pelanggan yang puas dengan kualitas produk atau jasa yang dibeli dari suatu organisasi menjadi pelanggan yang dapat diandalkan. Oleh karna itu kepuasan pelanggan sangat penting.

Kotler dan Keller (2012) menyatakan bahwa kepuasan pelanggan tergantung pada kinerja barang sesuai dengan harapan pelanggan setelah pembelian. Lin (2011) menjelaskan bahwa kepuasan pelanggan dihasilkan dari pengukuran produk dan layanan sesuai dengan pengalaman sebelumnya pelanggan serta evakuasi secara keseluruhan pada pengalaman mengkonsumsi.

Menurut Fandy Tjiptono dan Gregorius Chandra (2012 : 57) manfaat kepuasan pelanggan secara garis besar, kepuasan pelanggan memberikan dua manfaat utama bagi perusahaan, yaitu berupa loyalitas pelanggan dan penyebaran (advertising) dari mulut ke mulut atau yang biasa disebut dengan istilah gethok tular positif. Secara lebih rinci, manfaat-manfaat spesifik kepuasan pelanggan bagi perusahaan mencakup: dampak positif pada loyalitas pelanggan; berpotensi menjadi sumber pendapatan masa depan (terutama melalui pembelian ulang, crossselling, dan up-selling); menekan biaya transaksi pelanggan dimasa depan (terutama biaya-biaya komunikasi, penjualan dan layanan pelanggan); menekan volatilasi dan resiko berkenaan dengan prediksi aliran kas masa depan; meningkatnya toleransi harga (terutama kesediaan untuk membayar harga premium dan pelanggan tidak mudah tergoda untuk beralih pemasok); rekomendasi gethok tular positif; pelanggan cenderung lebih reseptif terhadap product-line extension, brand extension, dan new add-on service yang ditawarkan perusahaan; serta meningkatnya bargaining power relatif perusahaan terhadap jejaring pemasok, mitra bisnis, dan saluran distribusi.

\section{Metode Pengukuran Kepuasan Pelanggan}

Menurut Kotler yang dikutip oleh Fandy Tjiptono (2011:315) ada beberapa metode yang dipergunakan setiap perusahaan untuk mengukur dan memantau kepuasan pelanggannya dan pelanggan peasaing. Kotler mengidentifikasi empat metode untuk mengukur kepuasan pelanggan, antara lain:

1. Sistem keluhan dan Saran

Suatu perusahaan yang berorientasi pada pelanggan akan memberikan kesempatan yang luas pada para pelanggannya untuk menyampaikan saran dan keluhan, misalnya dengan menyediakan kotak saran, kartu komentar dan lain-lain. Informasi dari pelanggan ini akan memberikan masukan dan ide-ide bagi perusahaan agar bereaksi dengan tanggap dan cepat dalam menghadapi masalah-masalah yang timbul. Sehingga perusahaan akan tahu apa yang dikeluhkan oleh para pelanggan-nya dan segera memperbaikinya. Metode ini berfokus pada identifikasi masalah dan juga pengumpulan saran-saran dari pelanggan-nya langsung.

2. Ghost Shopping (Mystery Shopping)

Salah satu cara memperoleh gambaran mengenai kepuasan pelanggan adalah dengan mempekerjakan beberapa orang ghost shopers untuk berperan atau berpura-pura sebagai pelanggan potensial. Sebagai pembeli potensial terhadap produk dari perusahaan dan juga dari produk pesaing. Kemudian mereka akan melaporkan temuannya mengenai kekuatan dan kelemahan dari produk perusahaan dan pesaing berdasarkan pengalaman mereka dalam pembelian produk-produk tersebut. Selain itu ghost shopper juga bisa mengamati cara pe- 
nanganan terhadap setiap keluhan yang ada, baik oleh perusahaan yang bersangkutan maupun pesaingnya.

3. Lost Customer Analysis

Perusahaan akan menghubungi para pelanggannya atau setidaknya mencari tahu pelanggannya yang telah berhenti membeli produk atau yang telah pindah pemasok, agar dapat memahami penyebab mengapa pelanggan tersebut berpindah ke tempat lain. Dengan adanya peningkatan customer lost rate, dimana peningkatan customer lost rate menunjukkan kegagalan perusahaan dalam memuaskan pelanggannya.

4. Survei Kepuasan Pelanggan

Sebagian besar riset kepuasan pelanggan dilakukan dengan menggunakan metode survei, baik survei melalui pos, telepon, email, website, maupun wawancara langsung. Melalui survei perusahaan akan memperoleh tanggapan dan balikan secara langsung (feedback) dari pelanggan dan juga akan memberikan kesan positif terhadap para pelanggannya.

\section{Pengukuran Kepuasan Pelanggan}

Menurut Fandy Tjiptono (2012 : 320) pengukuran kepuasan dilakukan dengan berbagai macam tujuan, diantaranya :

- Mengidentifikasi keperluan (requitment) pelanggan (importance ratings), yakni aspek-aspek yang dinilai penting oleh pelanggan dan mempengaruhi apakah ia puas atau tidak.

- Menentukan tingkat kepuasan pelanggan terhadap kinerja organisasi pada aspek-aspek penting.

- Membandingkan tingkat kepuasan pelanggan terhadap perusahaan dengan tingkat kepuasan pelanggan terhadap organisasi lain, baik pesaing langsung maupun tidak langsung.

- Mengidentifikasi PFI (Priorities For Improvement) melalui analisa gap antara skor tingkat kepentingan (importance) dan kepuasan.

- Mengukur indeks kepuasan pelanggan yang bisa menjadi indikator handal dalam memantau kemajuan perkembangan dari waktu ke waktu.

\section{Strategi Memuaskan Pelanggan}

Strategi yang diterapkan berbagai organisasi dalam rangka memuaskan pelanggan menurut Fandy Tjiptono dan Chandra (2012 : 70) setidaknya ada delapan strategi, yaitu:

1. Manajemen ekspektasi pelanggan

Manajemen ekspektasi pelanggan adalah berusaha mengedukasi pelanggan adalah mereka yang benar-benar memahami peran, hak, dan kewajibannya berkenaan dengan produk/jasa. Beberapa perusahaan bahkan mencoba menerapkan kiat "under promise, over delivery" agar kinerja bisa melebihi ekspektasi pelanggan.

2. Relationship Marketing and Management Relationship Marketing (RM) berfokus pada upaya menjalin relasi positif jangka panjang yang saling menguntungkan dengan stakeholder utama perusahaan.Gummesson (2002) yang dikutip oleh Fandy Tjiptono (2012) merumuskan pentingnya kemungkinan relasi yang dikelompokkan dalam classic market relationship, special market relationship, mega relationship, dan nano relationship.

3. After Marketing

After marketing menekankan pentingnya orientasi pelanggan saat ini (current customer) sebagai cara yang lebih cost effective untuk membangun bisnis yang menguntungkan. Pencetusnya Terry Vavra yang merumuskan lima kunci implikasi after marketing : (1) Acquainting, yakni berusaha mengenal para pelanggan dan perilaku pembelian serta kebutuhan mereka, termasuk mengidentifikasi "high value customer"; (2) Acknowledging, yaitu berusaha menunjukkan kepada para pelanggan bahwa mereka dikenal secara personal, misalnya dengan merespon setiap komunikasi atau korespondensi dari para pelanggan secepat mungkin; (3) Appreciating, yakni mengapresiasi pelanggan dan bisnisnya; (4) Analyzing, yaitu menganalisis informasiinformasi yang disampaikan pelanggan melalui komunikasi dan korespondensi mereka; (5) Acting, yakni menindaklanjuti setiap masukan yang didapatkan dari pelanggan dan menunjukkan pada mereka bahwa perusahaan siap mendengarkan dan siap mengubah prosedur operasi atau produk/jasa dalam rangka memuaskan mereka secara lebih efektif.

4. Strategi Retensi Pelanggan

Strategi retensi pelanggan mirip dengan after marketing. Strategi ini berusaha meningkatkan retensi pelanggan melalui pemahaman atas faktor-faktor yang menyebabkan pelanggan beralih pemasok.dengan kata lain, strategi ini mencoba menekan price defectors (beralih pemasok karena mengejar harga lebih mudah), product defectors (menemukan produk superior di tempat lain), service defectors (mendapatkan layanan lebih bagus ditempat lain), market defectors (pindah kepasar lain), technological defectors (beralih ke teknologi lain) dan organizational defectors (beralih karena tekanan politik). 
5. Superior Customer Service

Strategi superior customer service diwujudkan dengan cara menawarkan layanan yang lebih baik dibandingkan para pesaing. Implementasinya bisa beranekaragam, diantaranya garansi internal dan eksternal jaminan, pelatihan cara penggunaan produk, konsultasi teknis, saran pemakaian produk alternatif, peluang penukaran atau pengembalian produk yang tidak memuaskan, reparasi komponen yang rusak/cacat, penyediaan suku cadang pengganti, penindaklanjutan kontak dengan pelanggan, informasi berkaladari perusahaan, klub/organisasi pemakai produk, pemantauan dan penyesuaian produk untuk memenuhi perubahan kebutuhan pelanggan, dan seterusnya.

6. Technology Infusion Strategy

Technology infusion strategy berusaha me manfaatkan kecanggihan teknologi untuk meningkatkan dan memuaskan pengalaman service encounter pelanggan, baik dalam hal customization dan fleksibilitas, perbaikan pemulihan layanan, maupun penyediaan spontaneous delight. Salah satu bentuknya SST (Self-servive Technologies) yang memungkinkan pelanggan menciptakan produk/jasa bagi dirinya sendiri.

7. Strategi Penanganan Komplain Secara Efektif Strategi penanganan complain secara efektif mengandalkan empat aspek penting. Yaitu : (1) empati terhadap pelanggan; (2) kecepatan dalam penanganan setiap keluhan; (3) kewajaran atau keadilan dalam me- mecahkan permasalahan atau complain; (4) kemudahan bagi konsumen untuk mengkontrak perusahaan. Bagi perusahaan, complain sebetulnya merupakan kesempatan berharga untuk memperbaiki hubungannya dengan pelanggan yang kecewa, menghindari publisitas negatif, dan menyempurnakan layanan di masa datang.

8. Strategi Pemulihan Layanan

Strategi pemulihan layanan berusaha menangani setiap masalah dan belajar dari kegagalan produk/layanan, serta melakukan perbaikan demi penyempurnaan layanan organisasi. Implementasinya bisa berupa jaminan layanan tanpa syarat, pemberdayaan karyawan, penyelesaian kegagalan layanan secara cepat, dan strategi manajemen zero defection. Contoh spesifikasinya antara lain permohonan maaf atas kesalahan yang terjadi, kompensasi atau ganti rugi, pengembalian uang, penjelasan atas penyebab kegagalan produk/layanan, pengerjaan ulang dan seterusnya. Riset menunjukkan bahwa kepuasan terhadap pemulihan layanan berkontribusi positif terhadap minat pembelian ulang, loyalitas dan komitmen pelanggan, trust, dan persepsi positif pelanggan terhadap fairness.

Berdasarkan pengertian kepuasan pelanggan diatas, maka dapat disimpulkan bahwa penilaian tentang ekspektasi pelanggan dengan mengevaluasi total pada produk/jasa dengan membandingkan kinerja (hasil) dan harapan konsumen.

\begin{tabular}{|c|c|c|c|}
\hline \multicolumn{4}{|c|}{ Hasil Penelitian yang Relevan } \\
\hline PENELITI/TAHUN & JUDUL & METODE PENELITIAN & HASIL DARI PENELITIAN \\
\hline $\begin{array}{l}\text { Jurnal ilmiah Arlina Nurbaity } \\
\text { Lubis dan Martin, Staf } \\
\text { pengajar FE USU \& Alumni } \\
\text { FE USU }\end{array}$ & $\begin{array}{l}\text { Pengaruh Harga (Price) dan } \\
\text { kualitas Pelayanan (Service } \\
\text { Quality) terhadap kepuasan } \\
\text { pasien rawat inap di RSU } \\
\text { Deli Medan }\end{array}$ & $\begin{array}{l}\text { Metode penelitian ini } \\
\text { menggunakan metode } \\
\text { analisis deskriptif-kuanlitatif } \\
\text { dengan pendekatan analisis } \\
\text { regresi berganda. } \\
\text { Metode ini untuk } \\
\text { mengetahui besarnya } \\
\text { hubungan dan pengaruh } \\
\text { variabel independen (harga } \\
\text { dan kualitas pelayanan) } \\
\text { terhadap variabel dependen } \\
\text { (kepuasan pasien) }\end{array}$ & $\begin{array}{l}\text { 1. Variabel harga dan kualitas pelayanan memiliki } \\
\text { pengaruh yang signifikan terhadap kepuasan } \\
\text { pasien rawat inap di RSU Deli Medan, harga } \\
\text { dan kualitas pelayanan yang ditawarkan oleh } \\
\text { RSU Deli Medan dinilai sangat baik sehingga } \\
\text { kepuasan pasien juga tercapai dengan baik. } \\
\text { 2. Berdasarkan uji-t bahwa variabel harga adalah } \\
\text { variabel yang paling dominan terhadap kepuasan } \\
\text { pasien, hal ini menunjukkan bahwa harga yang } \\
\text { ditawarkan oleh RSU Deli Medan sesuai dengan } \\
\text { pelayanan yang diberikan sehingga tercipta } \\
\text { suatu kepuasan pasien. } \\
\text { 3. Berdasarkan koefisien determinasi diketahui } \\
\text { bahwa variabel harga dan kualitas pelayanan } \\
\text { secara signifikan berpengaruh terhadap } \\
\text { kepuasan pasien. }\end{array}$ \\
\hline $\begin{array}{l}\text { Jurnal Ilmiah Pamela } \\
\text { Montung, Jantje Sepang, } \\
\text { Decky Adare. Universitas } \\
\text { Sam Ratulangi Manado } \\
\text { Tahun } 2015\end{array}$ & $\begin{array}{l}\text { Pengaruh Kualitas Produk, } \\
\text { Kualitas Layanan dan } \\
\text { Persepsi Harga Terhadap } \\
\text { Kepuasan Pelanggan di } \\
\text { Restoran Kawan Baru }\end{array}$ & $\begin{array}{l}\text { Penelitian ini adalah } \\
\text { penelitian asosiatif, dengan } \\
\text { menggunakan teknik random } \\
\text { sampling, metode analisis } \\
\text { regresi berganda }\end{array}$ & $\begin{array}{l}\text { Berdasarkan hasil penelitian yang telah dilakukan, } \\
\text { kualitas layanan berpengaruh positif terhadap } \\
\text { kepuasan pelanggan dibuktikan dengan hasil } \\
\text { statistik uji-t yang memiliki nilai signifikansi lebih } \\
\text { kecil dari } 5 \% \text {.selain itu nilai uji-t yang diperoleh } \\
\text { di mana }_{\text {hitung }} \text { lebih besar dari nilai } t_{\text {tabel }} \text { dengan } \\
\text { koefisien regresi yang bernilai positif. Kualitas } \\
\text { layanan merupakan variabel kedua yang paling } \\
\text { berpengaruh terhadap kepuasan pelanggan, } \\
\text { hasil ini menunjukkan bahwa hipotesis } 3 \text { yang } \\
\text { menyatakan kualitas layanan berpengaruh terhadap } \\
\text { kepuasan pelanggan diterima atau }\end{array}$ \\
\hline
\end{tabular}




\begin{tabular}{|c|c|c|c|}
\hline & & & $\begin{array}{l}\text { terbukti. Kualitas layanan juga merupakan salah } \\
\text { satu variabel yang terkuat berpengaruh terhadap } \\
\text { kepuasan pelanggan hasil penelitian ini mendukung } \\
\text { penelitian Tumangkeng (2014) dan Gulla (2015) di } \\
\text { mana dalam penelitian tersebut dan penelitian ini } \\
\text { sama-sama menemukan bahwa kualitas layanan } \\
\text { berpengaruh terhadap kepuasan pelanggan. }\end{array}$ \\
\hline $\begin{array}{l}\text { Skripsi Bunga Caecaria } \\
\text { Dwihapsari. Universitas } \\
\text { Diponegoro Tahun } 2012\end{array}$ & $\begin{array}{l}\text { Analisis Pengaruh Kualitas } \\
\text { Pelayanan dan Persepsi } \\
\text { Harga Terhadap Kepuasan } \\
\text { Konsumen Dalam } \\
\text { Menggunakan Jasa Pada } \\
\text { Oryza Tour }\end{array}$ & $\begin{array}{l}\text { Metode analisis deskriptif } \\
\text { - Analisis Kuantitatif. } \\
\text { menggunakan teknik } \\
\text { non probality sampling. } \\
\text { Sedangkan jenis non } \\
\text { probality sampling yang } \\
\text { digunakan adalah accidental } \\
\text { sampling }\end{array}$ & $\begin{array}{l}\text { Berdasarkan penelitian ini, hasil analisis regresi } \\
\text { berganda yaitu, } \mathrm{Y}=0,310 \mathrm{X}_{1}+0,221 \mathrm{X}_{2}+0,414 \mathrm{X}_{3} \text {. } \\
\text { Variabel independen yang paling berpengaruh } \\
\text { terhadap variabel dependen adalah variabel } \\
\text { kemampuan berkomunikasi }(0,414) \text { di ikuti oleh } \\
\text { variabel kualitas pelayanan }(0,310) \text { dan terakhir } \\
\text { adalah variabel persepsi harga }(0,221) \text {. Hasil uji-t } \\
\text { membuktikan bahwa semua variabel independen } \\
\text { mempunyai pengaruh positif terhadap variabel } \\
\text { dependen yaitu kepuasan konsumen. Dan koefisien } \\
\left.\text { (adjustmed } \mathrm{R}^{2}\right) \text { yang diperoleh sebesar } 0.752 \text {. hal } \\
\text { ini berarti } 75,2 \% \text { kepuasan konsumen dipengaruhi } \\
\text { oleh variabel kualitas pelayanan, persepsi harga, } \\
\text { dan kemampuan berkomunikasi. Dan sisanya yaitu } \\
24,8 \% \text { dipengaruhi variabel lain. }\end{array}$ \\
\hline $\begin{array}{l}\text { Jurnal Ilmiah Nuria Anindita } \\
\text { Putri. Universitas Surabaya } \\
\text { Tahun } 2013\end{array}$ & $\begin{array}{l}\text { Hubungan Antara Harga dan } \\
\text { Kualitas Layanan Dengan } \\
\text { Kepuasan Pelanggan } \\
\text { Blackberry Telkomsel }\end{array}$ & $\begin{array}{l}\text { Metode penelitian } \\
\text { Yang diterapkan } \\
\text { Dalam penelitian ini adalah } \\
\text { analisis regresi berganda, } \\
\text { dengan menggunakan teknik } \\
\text { incidental sampling. }\end{array}$ & $\begin{array}{l}\text { Berdasarkan penelitian yang dilakukan pada } \\
145 \text { pengguna layanan Blackberry Telkomsel di } \\
\text { Universitas Surabaya, ditemukan adanya hubungan } \\
\text { antara harga dan kualitas layanan Blackberry } \\
\text { dengan kepuasan pelanggan Telkomsel. Hal ini } \\
\text { dilihat dari hasil uji hipotesis menggunakan teknik } \\
\text { analisis korelasi kendall's yaitu }: \mathrm{R}=0.563 \text { dan } \\
\mathrm{p}=0.000 \text {. nilai signifikansi }(\mathrm{p}=0.000)<0.05, \\
\text { menunjukkan bahwa } \mathrm{H}_{0} \text { ditolak, berarti hipotesis } \\
\text { diterima. Sama halnya antara harga dengan } \\
\text { kepuasan pelanggan dan antara kualitas layanan } \\
\text { dengan kepuasan pelanggan. Masing-masing } \\
\text { memiliki nilai } r=0.263 \text { dan } 0.41 \text { dengan nilai } \\
\text { signifikansi yang sama yaitu } 0.000 \text {. semakin tinggi } \\
\text { kepuasan pelanggan maka semakin dipengaruhi } \\
\text { oleh harga dan kualitas layanan yang diberikan. }\end{array}$ \\
\hline
\end{tabular}

\section{Kerangka Pemikiran}

Berdasarkan masalah dan kajian teori diatas yang telah peneliti uraikan sebelumnya, maka peneliti akan menulis tentang Analisis Hubungan Kualitas Pelayanan Dan Persepsi Harga Dengan Kepuasan Konsumen (Studi Kasus Di Ruang Kenanga Rawat Inap Rumah Sakit Umum Daerah Kabupaten Tangerang) uraian teori di atas dapat digambarkan kerangka pemikiran seperti pada gambar 2.1. sebagai berikut :

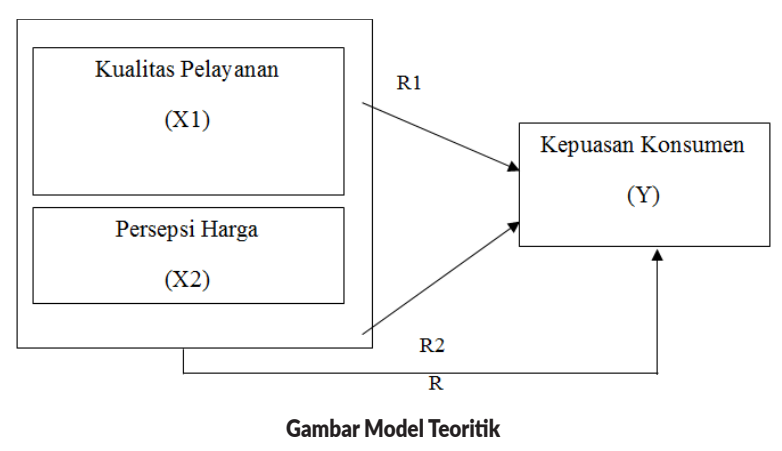

1. Analisis hubungan kualitas pelayanan dengan kepuasan konsumen :

$\mathrm{H}_{0}$ : Variabel independen (Analisis hubungan kualitas pelayanan) secara parsial tidak terdapat hubungan signifikan dengan variabel dependen (Kepuasan Konsumen)
$\mathrm{H}_{1}$ : Variabel independen (Analisis hubungan Kualitas Pelayanan) secara parsial terdapat hubungan signifikan dengan Variabel (Kepuasan Konsumen)

2. Hubungan persepsi harga dengan kepuasan Konsumen:

$\mathrm{H}_{0}$ : Variabel independen (Persepsi Harga) secara parsial tidak terdapat hubungan signifikan dengan variabel dependen (Kepuasan Konsumen)

$\mathrm{H}_{1}$ : Variabel independen (Persepsi Harga) secara parsial terdapat hubungan signifikan dengan variabel dependen (Kepuasan Konsumen)

3. Analisis Hubungan Kualitas Pelayanan dan Persepsi Harga secara bersama-sama terdapat hubungan dengan kepuasan Konsumen

$\mathrm{H}_{0}$ : Variabel-variabel independen (Analisis Hubungan Kualitas Pelayanan dan Persepsi Harga) secara bersama-sama tidak terdapat hubungan signifikan dengan variabel dependen (Kepuasan Konsumen).

$\mathrm{H}_{1}$ : Variabel-variabel independen (Analisis Hubungan Kualitas Pelayanan dan Persepsi Harga) secara bersamasama terdapat hubungan signifikan dengan variabel dependen (Kepuasan Konsumen). 


\section{Pembatasan Masalah}

Sehubungan dengan keterbatasan waktu, biaya dan tenaga penulis, membatasi dengan judul Analisis Hubungan Kualitas Pelayanan Dan Persepsi Harga Dengan Kepuasan Konsumen (Studi Kasus Di Ruang Kenanga Instalasi Rawat Inap Rumah Sakit Umum Daerah Kabupaten Tangerang). Maka faktor-faktor yang menganalisa hubungan kualitas pelayanan dan persepsi harga variabel independen dengan kepuasan konsumen variabel dependen.

\section{METODE}

\section{Tempat dan Waktu Penelitian}

Dalam penelitian ini penulis mengunakan metode penelitian kuantitatif, dilakukan dengan menggunakan pendekatan metode survey non kausal korelasional. Metode survey digunakan untuk mendapatkan data dari tempat tertentu yang alamiah (bukan buatan), tetapi peneliti melakukan perlakuan dalam pengumpulan data, misalnya dengan mengedarkan kuesioner, test, wawancara terstruktur dan sebagainya. (Sugiono, 2013 : 11). Penelitian ini dilaksanakan di Rumah Sakit Umum Daerah Kabupaten Tangerang, yang beralamat di jalan Jenderal Ahmad Yani No. 9 Tangerang.

\section{Populasi}

Populasi adalah keseluruhan obyek/subyek penelitian. Sedangkan sampel adalah bagian atau wakil populasi yang diteliti. Sampel terdiri dari bagian populasi terjangkau yang dapat dipergunakan sebagai subjek penelitian melalui sampling. Sampel adalah bagian atau wakil populasi yang diteliti. Populasi dalam penelitian ini adalah pasien dirawat inap ruang Kenanga RSUD Kab. Tangerang. Penelitian ini menggunakan sebanyak 87 orang sebagai sampel.

\section{HASIL dan PEMBAHASAN Hasil}

Berdasarkan hasil pengolahan SPSS pada variabel-variabel maka :

\begin{tabular}{|c|c|c|c|c|c|c|}
\hline \multicolumn{7}{|c|}{ Hasil Analisis Regresi Sederhana Variabel $\mathbf{X}_{1}$} \\
\hline \multicolumn{7}{|c|}{ Coefficients $^{a}$} \\
\hline \multirow{2}{*}{\multicolumn{2}{|c|}{ Model }} & \multicolumn{2}{|c|}{$\begin{array}{l}\text { Unstandardized } \\
\text { Coefficients }\end{array}$} & \multirow{2}{*}{\begin{tabular}{|c|}
$\begin{array}{c}\text { Standardized } \\
\text { Coefficients }\end{array}$ \\
Beta \\
\end{tabular}} & \multirow[b]{2}{*}{$\mathrm{t}$} & \multirow[b]{2}{*}{ Sig. } \\
\hline & & B & $\begin{array}{l}\text { Std. } \\
\text { Error }\end{array}$ & & & \\
\hline \multirow[t]{2}{*}{1} & (Constant) & 6.851 & 1.034 & & 6.626 & .000 \\
\hline & Kualitas Pelayanan $\left(X_{1}\right)$ & .353 & .028 & .803 & 12.435 & .000 \\
\hline
\end{tabular}

Hasil perhitungan analisa regresi sederhana variabel kualitas pelayanan terhadap kepuasan konsumen menghasilkan arah regresi b sebesar 0,353 dan konstanta a sebesar 6,851. Dengan demikian bentuk hubungan antara kedua variabel tersebut dapat digambarkan oleh persamaan $\mathrm{Y}$ $=0,353+6,851$ selanjutnya nilai positif 6,851 yang terdapat koefesien regresi variabel kualitas pelayanan terhadap variabel terikat adalah searah, dimana kenaikan satu satuan variabel kualitas pelayanan akan menyebabkan kenaikan dalam kepuasan konsumen.

\begin{tabular}{|c|c|c|c|c|c|c|}
\hline \multicolumn{7}{|c|}{ Hasil Analisis Regresi Sederhana Variabel $\mathbf{X}_{2}$} \\
\hline \multicolumn{7}{|c|}{ Coefficients $^{a}$} \\
\hline \multirow{2}{*}{\multicolumn{2}{|c|}{ Model }} & \multicolumn{2}{|c|}{$\begin{array}{l}\text { Unstandardized } \\
\text { Coefficients }\end{array}$} & \multirow{2}{*}{$\begin{array}{c}\begin{array}{c}\text { Standardized } \\
\text { Coefficients }\end{array} \\
\text { Beta }\end{array}$} & \multirow[b]{2}{*}{$t$} & \multirow[b]{2}{*}{ Sig. } \\
\hline & & B & $\begin{array}{c}\text { Std. } \\
\text { Error }\end{array}$ & & & \\
\hline \multirow[t]{2}{*}{1} & (Constant) & 4.455 & .893 & & 4.990 & .000 \\
\hline & Persepsi Harga $\left(X_{2}\right)$ & .848 & .050 & .880 & 17.085 & .000 \\
\hline
\end{tabular}

Hasil perhitungan SPSS, analisa regresi sederhana variabel persepsi harga dengan kepuasan konsumen menghasilkan arah regresi b sebesar 0,848 dan konstanta a sebesar 4,455. Dengan demikian hubungan antara kedua variabel tersebut dapat dapat digambarkan oleh persamaan regresi $\mathrm{Y}=4,455+0,848$ selanjutnya nilai positif yang terdapat pada koefesien regresi variabel persepsi harga dan dengan variabel kepuasan konsumen adalah searah, dimana kenaikan satu satuan variabel persepsi harga akan menyebabkan kenaikan kepuasan konsumen 0,848 .

\begin{tabular}{|c|c|c|c|c|c|c|}
\hline \multicolumn{7}{|c|}{ Hasil Analisis Regresi Linier Berganda } \\
\hline \multicolumn{7}{|c|}{ Coefficients $^{\mathrm{a}}$} \\
\hline \multirow{2}{*}{\multicolumn{2}{|c|}{ Model }} & \multicolumn{2}{|c|}{$\begin{array}{l}\text { Unstandardized } \\
\text { Coefficients }\end{array}$} & \multirow{2}{*}{$\begin{array}{c}\text { Standardized } \\
\text { Coefficients } \\
\text { Beta }\end{array}$} & \multirow[b]{2}{*}{$t$} & \multirow[b]{2}{*}{ Sig. } \\
\hline & & B & $\begin{array}{l}\text { Std. } \\
\text { Error }\end{array}$ & & & \\
\hline \multirow[t]{3}{*}{1} & (Constant) & 4.448 & .896 & & 4.965 & .000 \\
\hline & Persepsi Harga $\left(\mathrm{X}_{2}\right)$ & .927 & .133 & .962 & 6.984 & .000 \\
\hline & Kualitas Pelayanan $\left(X_{1}\right)$ & -.039 & .060 & -089 & .644 & .521 \\
\hline
\end{tabular}

Hasil penelitian statistik analisis regresi berganda terhadap variabel kepuasan konsumen atas kualitas pelayanan dan persepsi harga secara bersama-sama menghasilkan arah regersi b1 sebesar -0.039 dan b2 0.927 serta konstanta sebesar 4.448. Dengan demikian bentuk hubungan antara kedua variabel tersebut dapat digambarkan oleh persamaan regresi $\mathrm{Y}=4.448+-0,039+0,927$ ini menggambarkan arah hubungan variabel kualitas pelayanan dan persepsi harga dengan variabel terikat kepuasan konsumen. 


\begin{tabular}{|c|c|c|c|c|c|c|}
\hline \multicolumn{7}{|c|}{ Uji Signifikansi Pengaruh Parsial (t) } \\
\hline \multicolumn{7}{|c|}{ Coefficients $^{\mathrm{a}}$} \\
\hline \multirow{2}{*}{\multicolumn{2}{|c|}{ Model }} & \multicolumn{2}{|c|}{$\begin{array}{l}\text { Unstandardized } \\
\text { Coefficients }\end{array}$} & \multirow{2}{*}{$\begin{array}{c}\text { Standardized } \\
\text { Coefficients }\end{array}$} & \multirow[b]{2}{*}{ t } & \multirow[b]{2}{*}{ Sig. } \\
\hline & & B & $\begin{array}{l}\text { Std. } \\
\text { Error }\end{array}$ & & & \\
\hline \multirow[t]{3}{*}{1} & (Constant) & 4.448 & .896 & & 4.965 & .000 \\
\hline & Persepsi Harga $\left(X_{2}\right)$ & .927 & .133 & .962 & 6.984 & .000 \\
\hline & Kualitas Pelayanan $\left(X_{1}\right)$ & -039 & .060 & -089 & .644 & .521 \\
\hline
\end{tabular}

Hasil dari uji coba Coefesien, pada penelitian ini dikemukakan nilai (constant) kualitas pelayanan $=-0.039$ dan $B=-0,089$, serta persepsi harga $\mathrm{t}_{\text {hitung }}$ dan tingkat signifikan $=0.000$. Nilai (constans) persepsi harga $=0.927$ dan $\mathrm{B}=0.962$ serta harga t hitung dan tingkat signifikan $=0.521$.

Berdasarkan tabel diatas, dapat diketahui bahwa $\mathrm{t}_{\text {hitung }}$ diperoleh untuk seluruh variabel bebas adalah -0.644 dan 6.984 dengan nilai signifikansi sebesar 0.000 jauh dibawah nial a yang telah ditentukan yaitu 0.05 sedangkan nilai signifikansi untuk persepsi harga lebih kecil dari nilai a yang ditentukan yaitu sebesar 0.05 dengan hasil ini berarti bahwa terdapat hubungan dan pengaruh yang positif antara kualitas pelayanan dengan kepuasan konsumen begitupula dengan persepsi harga dapat disimpulkan bahwa persepsi harga terdapat pengaruh dan hubungan yang positif antara persepsi harga dengan kepuasan konsumen.

\begin{tabular}{|c|c|c|c|c|c|c|}
\hline \multicolumn{7}{|c|}{ Hasil Uji Signifikansi Simultan (Uji Statistik F) } \\
\hline \multicolumn{7}{|c|}{ ANOVA $^{\mathrm{a}}$} \\
\hline \multicolumn{2}{|c|}{ Model } & $\begin{array}{l}\text { Sum of } \\
\text { Squares }\end{array}$ & df & $\begin{array}{l}\text { Mean } \\
\text { Square }\end{array}$ & $\mathrm{F}$ & Sig. \\
\hline 1 & Regression & 244.506 & 1 & 244.506 & 154.620 & $.000 \mathrm{~b}$ \\
\hline & Residual & 134.414 & 85 & 1.581 & & \\
\hline & Total & 378.920 & 86 & & & \\
\hline & ent Variab & uasan $\mathrm{Kc}$ & & & & \\
\hline
\end{tabular}

Tabel Anova diatas menunjukkan apakah signifikansi dari model linier yang digunakan sudah tepat atau belum. Berdasarkan tabel diatas, dapat diketahui bahwa nilai $\mathrm{F}$ diperoleh adalah sebesar 154.620 dengan nilai signifikan 0.00, nilai signifikan yang diperoleh jauh lebih kecil dari a yang ditentukan 0.05 yang berarti bahwa terdapat hubungan positif, dan sebaliknya jika nilai signifikansi yang diperoleh lebih besar dari 0.05 berarti tidak terdapat hubungan positif antara variabel bebas (kualitas pelayan dan persepsi harga) dengan variabel terikat (kepuasan konsumen) dengan demikian dapat diambil kesimpulan bahwa model tersebut menjelaskan atau menerangkan hubungan antara kualitas pe- layanan dan persepsi harga dengan kepuasan konsumen.

Koefesien Determinasi mengukur seberapa jauh kemampuan model dalam menerangkan variabel-variabel dependen. Adapun besar hubungan dan pengaruh yang diperoleh dapat dilihat pada tabel model summary berikut :

\begin{tabular}{|c|c|c|c|c|c|c|c|c|c|}
\hline \multicolumn{10}{|c|}{ Koefesien Determinasi $\left(\mathbf{R}^{2}\right)$} \\
\hline \multicolumn{10}{|c|}{ Model Summary } \\
\hline \multirow[b]{2}{*}{ Model } & \multirow[b]{2}{*}{$R$} & \multirow[b]{2}{*}{$\begin{array}{c}R \\
\text { Square }\end{array}$} & \multirow[b]{2}{*}{$\begin{array}{c}\text { Ad- } \\
\text { justed R } \\
\text { Square }\end{array}$} & \multirow[b]{2}{*}{$\begin{array}{l}\text { Std. Error } \\
\text { of the } \\
\text { Estimate }\end{array}$} & \multicolumn{5}{|c|}{ Change Statistics } \\
\hline & & & & & $\begin{array}{c}\text { R } \\
\text { Square } \\
\text { Change }\end{array}$ & FChange & $d f 1$ & $d f 2$ & $\begin{array}{l}\text { Sig. F } \\
\text { Change }\end{array}$ \\
\hline 1 & $.803^{a}$ & .645 & .641 & 1.25751 & .645 & 154.620 & 1 & 85 & .000 \\
\hline $\begin{array}{l}\text { a. Pred } \\
\text { b. Dep }\end{array}$ & S. L & ll, KU & $\begin{array}{l}\text { Pelayana } \\
\text { Konsumer }\end{array}$ & & & & & & \\
\hline
\end{tabular}

Koefesien antara variabel hubungan kualitas pelayanan dan kepuasan konsumen adalah 0,803 menunjukkan tingkat hubungan yang sangat sangat kuat. Sedangkan Koefesien determinasi $\left(\mathrm{R}^{2}\right)$ adalah 0,645 artinya kuat, jadi koefesien determinasi dengan kepuasan konsumen 64,1\%.

\begin{tabular}{|c|c|c|c|c|c|c|c|c|c|}
\hline \multicolumn{10}{|c|}{ Koefesien Determinasi variabel $X_{2}$ terhadap $Y$} \\
\hline \multicolumn{10}{|c|}{ Model Summary } \\
\hline \multirow[b]{2}{*}{ Model } & \multirow[b]{2}{*}{$R$} & \multirow[b]{2}{*}{$\begin{array}{c}R \\
\text { Square }\end{array}$} & \multirow[b]{2}{*}{$\begin{array}{l}\text { Ad- } \\
\text { justed R } \\
\text { Square }\end{array}$} & \multirow[b]{2}{*}{$\begin{array}{l}\text { Std. Error } \\
\text { of the } \\
\text { Estimate }\end{array}$} & \multicolumn{5}{|c|}{ Change Statistics } \\
\hline & & & & & $\begin{array}{c}R \\
\text { Square } \\
\text { Change }\end{array}$ & FChange & df1 & df2 & $\begin{array}{l}\text { Sig.F } \\
\text { Change }\end{array}$ \\
\hline 1 & $.880^{\circ}$ & .774 & .772 & 1.00266 & .774 & 291.909 & 1 & 85 & .000 \\
\hline
\end{tabular}

Koefesien antara variabel kualitas pelayanan dan kepuasan konsumen adalah 0,880 menunjukkan tingkat hubungan yang kuat, sedangkan koefsien determinasi $\left(\mathrm{R}^{2}\right)$ adalah 0,774 artinya kuat, jadi koefesien determinasi dengan kepuasan konsumen adalah $77,2 \%$.

\begin{tabular}{|c|c|c|c|c|c|c|c|c|c|}
\hline \multicolumn{10}{|c|}{ Koefesien Determinasi variabel $X_{1}$ dan $X_{2}$ terhadap $Y$} \\
\hline \multicolumn{10}{|c|}{ Model Summary } \\
\hline \multirow[b]{2}{*}{ Model } & \multirow[b]{2}{*}{$R$} & \multirow[b]{2}{*}{$\begin{array}{c}R \\
\text { Square }\end{array}$} & \multirow[b]{2}{*}{$\begin{array}{c}\text { Ad- } \\
\text { justed R } \\
\text { Square }\end{array}$} & \multirow[b]{2}{*}{$\begin{array}{l}\text { Std. Error } \\
\text { of the } \\
\text { Estimate }\end{array}$} & \multicolumn{5}{|c|}{ Change Statistics } \\
\hline & & & & & $\begin{array}{c}R \\
\text { Square } \\
\text { Change }\end{array}$ & FChange & df1 & df2 & $\begin{array}{l}\text { Sig.F } \\
\text { Change }\end{array}$ \\
\hline 1 & $.881^{\circ}$ & .776 & .770 & 1.00613 & .776 & 145.157 & 2 & 84 & .000 \\
\hline $\begin{array}{l}\text { a. Pred } \\
\text { b. Dep }\end{array}$ & & & & 1, Perseps & & & & & \\
\hline
\end{tabular}

Dari tabel diatas menunjukkan bahwa terdapat hubungan antara kualitas pelayanan dengan kepuasan konsumen yaitu sebesar 0,881, sedangkan besar hubungan yang diperoleh adalah sebesar 0,776. Hal ini menunjukkan bahwa kualitas pelayanan dan kepuasan konsumen memberikan kontribusi sebesar $77,6 \%$ dengan kepuasan konsumen, sedangkan sisanya sebesar 22,4 $\%$ merupakan pengaruh faktor lain. 
Ketiga hipotesis yang dirumuskan dalam penelitian ini telah dibahas, hal ini menunjukkan bahwa hubungan kualitas pelayanan $\left(\mathrm{X}_{1}\right)$ dan persepsi harga $\left(\mathrm{X}_{2}\right)$ baik sendiri-sendiri maupun bersama-sama memiliki hubungan dengan kepuasan konsumen $(\mathrm{Y})$.

\section{PEMBAHASAN}

Pada hasil penelitian diatas, pembahasan mengenai masalah hubungan antara variabel kualitas pelayanan dan persepsi harga dengan kepuasan konsumen dapat dijelaskan sebagai berikut :

1. Penelitian diatas, jika berdasarkan fungsi regresi variabel kualitas pelayanan memiliki koefesien sebesar -0,089 dan dilihat dari hasil uji t pada variabel kualitas pelayanan menghasilkan $\mathrm{t}_{\text {hitung }}-0,644$ signifikan sebesar $0,000, \mathrm{~T}_{\text {hitung }}-0,644>$ dari $\mathrm{t}_{\text {tabel }}$ yang nilainya 1.658 dengan tingkat signifikan 0,521 kurang dari 0,05 maka dapat diketahui kualitas pelayanan memiliki hubungan yang positif dengan kepuasan konsumen, jika dilihat dengan persamaan regresi variabel kepuasan konsumen memiliki koefesien paling tinggi $-0,644$.

2. Persamaan regresi untuk variabel kualitas pelayanan memiliki nilai koefesien sebesar -0,089 dan dilihat adari uji t pada variabel persepsi harga adalah 0,6984 dan signifikan $0,521 . \mathrm{T}_{\text {hitung }}<\mathrm{t}_{\text {tabel }}$ yang nilainya 1.658 dengan tingkat signifikan 0,521 lebih dari 0,05, maka dapat diketahui bahwa kualitas pelayanan terdapat hubungan yang signifikan dengan kepuasan konsumen.

Dari ketiga gambaran hasil penelitian tersebut dapat diinterprestasikan sebagai berikut :

1. Kualitas pelayanan $\left(\mathrm{X}_{1}\right)$ mempunyai hubungan yang cukup kuat dengan kepuasan konsumen $(\mathrm{Y})$. Hipotesis yang diajukan adalah terdapat hubungan antara kualitas pelayanan dengan kepuasan konsumen, artinya $\mathrm{H}_{0}$ ditolak dan $\mathrm{H}_{\mathrm{a}}$ diterima.

2. Persepsi harga $\left(\mathrm{X}_{2}\right)$ mempunyai hubungan yang kuat dengan kepuasan konsumen $(\mathrm{Y})$. Hipotesis yang diajukan adalah terdapat hubungan antara persepsi harga dengan kepuasan konsumen, artinya $\mathrm{H}_{0}$ ditolak $\mathrm{H}_{\mathrm{a}}$ diterima.

3. Kualitas pelayanan $\left(\mathrm{X}_{1}\right)$ dan persepsi harga secara bersama-sama/secara simultan dengan kepuasan konsumen dapat diterima artinya $\mathrm{H}_{0}$ ditolak $\mathrm{H}_{\mathrm{a}}$ diterima.

\section{SIMPULAN \\ Kesimpulan}

Setelah dilakukan dari hasil penelitian maka dapat ditarik kesimpulan sebagai berikut :
1. Terdapat hubungan yang cukup signifikan antara variabel kualitas pelayanan $\left(\mathrm{X}_{1}\right)$ dengan kepuasan konsumen $(\mathrm{Y})$, adalah sign $0,000<\mathrm{P}=0,05$ dengan korelasi $\mathrm{r}=0,803$ dan determinasi $r^{2}=0,645$. Hubungan kedua variabel tersebut dapat digambarkan oleh persamaan regresi sederhana $\mathrm{Y}=0,353+$ 6,851 yang terdapat pada koefesien regresi variabel kualitas pelayanan $\left(\mathrm{X}_{1}\right)$, terhadap kepuasan konsumen $(\mathrm{Y})$ adalah searah, di mana kenaikan satu-satuan variabel kualitas pelayanan akan menyebabkan bertambahnya nilai kepuasan konsumen 0.353 , dengan demikian bahwa kualitas pelayanan merupakan prioritas yang harus dipertimbangkan oleh rumah sakit umum daerah kabupaten tangerang mengingat dari hasil kualitas pelayanan dapat mempengaruhi kepuasan konsumen.

2. Terdapat hubungan yang signifikan antara variabel persepsi harga $\left(\mathrm{X}_{2}\right)$ terhadap kepuasan konsumen $(\mathrm{Y})$, adalah sign $0,000<\mathrm{P}$ $=0,05$ dengan korelasi $r=0,880$ dan determinasi $r^{2}=0,774$. Hubungan antara kedua variabel tersebut dapat digambarkan oleh persamaan regresi sederhana $\mathrm{Y}=$ $4,455+0,848$ nilai positif 0,848 yang terdapat pada koefesien yang terdapat pada koefesien regresi variabel persepsi harga $\left(\mathrm{X}_{2}\right)$ dengan kepuasan konsumen $(\mathrm{Y})$ adalah searah dimana kenaikan satu-satuan variabel persepsi harga akan menyebabkan kenaikan kepuasan konsumen 0,848 artinya persepsi harga mampu memberikan pengaruh yang positif kepada masyarakat karena dapat meningkatkan kepuasan konsumen.

3. Terdapat hubungan yang signifikan antara kualitas pelayanan $\left(\mathrm{X}_{1}\right)$ dan persepsi harga $\left(\mathrm{X}_{2}\right)$ dengan kepuasan konsumen $(\mathrm{Y})$ adalah sign $0,000<\mathrm{P}=0,05$ dan $\mathrm{r}=88,1 \%$ sehingga $\mathrm{H}_{0}$ ditolak, artinya kualitas pelayanan dan persepsi harga secara simultan mempunyai hubungan yang positif dengan kepuasan konsumen (Y). dengan kontribusi sebesar $77,6 \%$ oleh kualitas pelayanan dan harga terhadap kepuasan konsumen.

\section{Saran}

1. Berdasarkan hal tersebut adapun yang dapat dilakukan oleh rumah sakit umum daerah Kabupaten Tangerang untuk dapat meningkatkan kualitas pelayanan kepada pasien dengan melakukan pelatihan-pelatihan kepada karyawannya, dengan demikian kepuasan konsumen dapat terus meningkat.

2. Pihak rumah sakit umum daerah Kabupaten Tangerang untuk dapat meningkatkan kepuasan konsumen dengan melakukan so- 
sialisasi kepada masyarakat dalam hal pengetahuan tentang kesehatan sehingga persepsi masyarakat tentang kesehatan dapat memberikan kepuasan yang terus meningkat.

3. Meningkatkan kualitas sumber daya manusia dan fasilitas-fasilitas penunjang seperti sarana dan prasarana dalam hal infrastruktur sehingga memberikan kenyamanan dan $\mathrm{ke}^{-}$ puasan bagi konsumen.

\section{DAFTAR PUSTAKA}

Arlina Nurbaity Lubis dan Martin. Tahun 2009. Jurnal Ilmiah. Pengaruh Harga (Price) dan Kualitas Pelayanan (Service Quality) Terhadap Kepuasan Pasien Rawat Inap Di RSU Deli Medan

Basu Swastha (2010). Pengaruh Low Price Guarantee Pada Evaluasi Konsumen Yang Dimoderasi Harga Referensi Citra Toko Dan Nama Merek. Yogyakarta.

Bunga Caecaria Dwihapsari. Tahun 2012. Skripsi. Analisis Pengaruh Kualitas Pelayanan Dan Persepsi Harga Terhadap Kepuasan Konsumen Dalam Menggunakan Jasa Pada Oryza Tour.

Daryanto \& Setyobudi (2014). Konsumen Dan Pelayanan Prima. Gaya Media

Desmita (2011). Psikologi Perkembangan Peserta Didik. Bandung. PT. Remaja Rasdakarya.

Fandy Tjiptono (2012). Service Management : Mewujudkan Layanan Prima. Yogyakarta.

Fitzsimmons (2011). Service Management.New York : McGraw Hill.

http ://kesehatan.komposiana.com/medis /2012/ 11/29/memahami define-sehat-512845.html

http ://www.anekanews.com/2011/03/konsep-sandefinisi-sehat.html

http ://www.rsu.tangerangkab.go.id

Jalaluddin Rakhmat. Psikologi Komunikasi. Remaja Resdakarya 2011.

Jusuf Suit Almasdi. Aspek Sikap Mental Dalam Manajemen Sumber Daya Manusia. Jakarta. Syiar Media 2012.

Kotler, PhilipAnd Gary Armstrong (2012). Principle Of Marketing, Fourteenth Edition. Pearson Education Limited, England.

Kotler \& Keller (2013) Manajemen Pemasaran. Jilid 2. Jakarta. Erlangga 2013.

Kotler \& Keller, (2012). Marketing Management edisi 14, Global Edition. Pearson Prentice Hall.

Lee, Simon; Abdou Illia., Lawson - Body, Assion. Perceived Price Of Dynamic Pricing. Journal of Industrial Management + Data Systems, 111 (4). 2011.

Lupiyoadi, Rambat. Manajemen Pemasaran Jasa : Berbasis Kompetensi. Salemba Empat 2014.

Malik \&Yaqoob,\& Aslam. The Impact of Price Perception, service quality, and brand image on customer loyalty (study of hospitality industry in Pakistan interdisciplinary, journal of contempory research in business vol 4 , no.5.2012

M. Yani (2012). Manajemen Sumber Daya Manusia. Penerbit Mitra Wacana Media

Nuria Anindita Putri. Tahun 2013. Jurnal Ilmiah. Hubungan Antara Harga dan Kualitas Layanan Dengan Kepuasan Pelanggan Blackberry Telkomsel

Pamela Montung, Jantje Sepang, Decky Adare. Tahun 2015. Pengaruh Kualitas Produk, Kualitas Layanan dan Persepsi Harga Terhadap Kepuasan Pelanggan Di Restoran Kawan Baru. Jurnal Ilmiah. Universitas Sam Ratulangi Manado.

Peter \& Olson. Consumer Behavior And Marketing Strategy. Boston McGraw-Hill 2008.

Sugiyono. (2013). Metode Penelitian Bisnis. Bandung Alpabeta

Suranto (2011). Komunikasi Interpersonal. Yogyakarta : Graha Ilmu

Siti Nur Fatoni. 2014. Pengantar Ilmu Ekonomi. CV. Pustaka Setia. Bandung

Siswanto. (2011). Pengantar Manajemen. Diterbitkan oleh PT. Bumi Akasara.

Sunyoto, Danang. (2013). Perilaku Konsumen (Panduan Riset Sederhana Untuk Mengenai Konsumen). Yogyakarta, CAPS (Center Of Academic Publishing Service).

Sumanto, (2014) Statiska Deskriptif. Diterbitkan oleh : CAPS (Center of Academic Publishing Service.

Sudaryono et al. (2013) Pengembangan Instrumen Penelitian Pendidikan. Penerbit : Yogyakarta - Graha Ilmu. 